\title{
3-Phosphoglycerate kinase: a glycolytic enzyme protein present in the cell wall of Candida albicans
}

\author{
Habib M. Alloush,† José L. López-Ribot, Barbara J. Mastenł \\ and W. LaJean Chaffin \\ Author for correspondence: W. LaJean Chaffin. Tel: +1 806743 2513. Fax: +1 8067432334.
e-mail: micwle@ttuhsc.edu
}

Department of Microbiology and Immunology, Texas Tech University Health Sciences Center, Lubbock, TX 79430, USA

\begin{abstract}
We have used a polyclonal antiserum to cell wall proteins of Candida albicans to isolate several clones from a CDNA $\lambda$ gt11 expression library. Affinitypurified antibody prepared to the fusion protein of one clone identified a $40 \mathrm{kDa}$ moiety present in cell wall extracts from both morphologies of the organism. Indirect immunofluorescence demonstrated expression of this moiety at the $C$. albicans cell surface. Sequencing of a pBluescript II genomic clone identified with the CDNA clone revealed an open reading frame for a 417 amino acid protein. The nucleotide sequence showed significant homology with 3-phosphoglycerate kinase (PGK) genes, with $88 \%, 77 \%$ and $76 \%$ nucleotide homology with the PGK genes from Candida maltosa,

Saccharomyces cerevisiae and Kluyveromyces lactis, respectively. The deduced amino acid sequence was consistent with this identification of the sequence as PGK1 of $C$. albicans. This finding was confirmed by a positive immunological response of a commercially available purified PGK from S. cerevisiae with the affinity-purified antibody against the fusion protein of the CDNA clone. The presence of PGK in the cell wall was confirmed by two additional methods. Cell wall proteins were biotinylated with a derivative that does not permeate the cell membrane to distinguish extracellular from cytosolic proteins. Biotinylated PGK was detected among the biotinylated proteins obtained following streptavidin affinity chromatography. Immunoelectron microscopy revealed that the protein was present at the outer surface of the cell membrane and cell wall as well as expected in the cytoplasm. Northern blot analysis revealed that the gene transcript was present in C. albicans cells growing under different conditions, including different media, temperatures and morphologies. Most of the enzyme activity was found in the cytosol. Low enzymic activity was detected in intact cells but not in culture filtrates. These observations confirmed that PGK is a bona fide cell wall protein of C. albicans.
\end{abstract}

Keywords: Candida albicans, cell wall, 3-phosphoglycerate kinase

\section{INTRODUCTION}

The cell wall of the opportunistic pathogen Candida albicans has been the focus of numerous studies (Cassone, 1989). Glucan and chitin constitute a rigid skeleton in which the protein fraction (mainly mannoproteins) is embedded (Cassone, 1989). For a number of years, it has been realized that there is a high degree of complexity associated with the protein component (Casanova \& Chaffin, 1991; Casanova et al., 1992; Chaffin \& Stocco, 1983; Pontón et al., 1993). Although a number of studies in recent years have focused on the identification of

†Present address: School of Biological Sciences, University of Bath, Bath BA2 7AY, UK.

$\ddagger$ Present address: Department of Pathology, University of New Mexico, School of Medicine, Albuquerque, NM 87131, USA.

Abbreviations: IIF, indirect immunofluorescence; $\beta$ ME, $\beta$-mercaptoethanol; PGK, 3-phosphoglycerate kinase.

The GenBank accession number for the sequence data reported in this paper is U25180. 
protein components, the identity and function of most of the proteins present in this organelle remain unknown. As the outermost part of the cell, the cell wall has important functions in the interaction between the fungal cells and their surrounding environment, and by extension, in the host-parasite interaction and in pathogenicity. Most of these functions, which include adhesion to inert and biological surfaces, antigen presentation and immunomodulation, and a role in morphogenesis (Calderone, 1993; Calderone \& Braun, 1991; Casanova et al., 1990; Cassone, 1989; Hostetter, 1994; Martínez et al., 1990), have been associated with the protein fraction, and have been postulated as virulence factors (Cutler, 1991).

We have previously reported the isolation of several cDNA clones for cell wall proteins and the use of the cloned sequence and antibody to the fusion protein to examine the expression of the gene and protein (Alloush et al., 1996). One of these cDNA clones was associated with a $40 \mathrm{kDa}$ protein which appeared to be constitutively expressed by both yeast cells and germ tubes. We report here the cloning and nucleotide sequence of the gene designated PGK1 that has extensive homology with genes specifying 3-phosphoglycerate kinase (PGK). The cellular localization and expression have been further investigated and the protein demonstrated to be a bona fide cell wall protein.

\section{METHODS}

Organisms and culture conditions. C. albicans 3153A was employed throughout this work. It was maintained by subculturing every 2-3 weeks on Sabouraud-dextrose plates. The organism was propagated as yeast cells or yeast cells bearing germ tubes as described previously (Casanova $e t$ al., 1989; López-Ribot \& Chaffin, 1994) in the minimal medium supplemented with amino acids described by Lee et al. (1975). For some experiments, C. albicans was grown in $2 \%(\mathrm{w} / \mathrm{v})$ yeast extract $/ 1 \%(\mathrm{w} / \mathrm{v})$ peptone $/ 2 \%(\mathrm{w} / \mathrm{v})$ glucose medium (YEPD) at 25 or $37^{\circ} \mathrm{C}$.

Preparation of cell wall extract. Protein and glycoprotein components of the walls were released from intact cells by treatment with $\beta$-mercaptoethanol $(\beta \mathrm{ME})$ as described previously (Casanova \& Chaffin, 1991; Casanova et al., 1992). Briefly, organisms were resuspended in ammonium carbonate buffer containing $1 \%(\mathrm{v} / \mathrm{v}) \beta \mathrm{ME}$ and incubated for $30 \mathrm{~min}$ at $37^{\circ} \mathrm{C}$ with shaking. After treatment, the cells were sedimented, and the supernatant fluid was recovered, dialysed against distilled water (four changes) for $48 \mathrm{~h}$ at $4{ }^{\circ} \mathrm{C}$, and concentrated by freeze-drying ( $\beta \mathrm{ME}$ extract). The total sugar content in the preparation was determined colorimetrically with mannose as a standard (Dubois et al., 1956).

Biotinylation of cell surface components. C. albicans yeast cells were grown as described above. Cell surface components were biotinylated with Sulfo-NHS-biotin (Pierce), which does not permeate the cell membrane (Cole et al., 1987), essentially as previously described by Casanova et al. (1992). Surface components were extracted as described above and biotinylated proteins were purified from a portion of the extract by affinity chromatography on immobilized streptavidin following the manufacturer's instructions (Pierce) as previously described (López-Ribot et al., 1996).

Isolation of the PGK1 gene. A pooled polyclonal rabbit antiserum previously described was prepared by combining antiserum prepared to different cell wall extracts (LópezRibot \& Chaffin, 1994). Several clones specifying different cell wall proteins were isolated from a $\lambda \mathrm{gt} 11$ cDNA expression library prepared from germ tube mRNA (Alloush et al., 1996). The $1.4 \mathrm{~kb}$ insert of one clone, originally designated $\mathrm{V}$, was amplified by PCR (GeneAmp PCR Reagent kit; Perkin Elmer). Primers in the vector sequences were $5^{\prime}$ ACGACTCCTGGAGCCCGTCAGTAT and $5^{\prime}$ TTGACACCAGACCAACTGGTAATG. The PCR product was labelled with [ $\left.{ }^{32} \mathrm{P}\right] \mathrm{ATP}$ by nick translation (Amersham) and used for hybridization screening of the genomic library by standard methods (Ausubel et al., 1988). For preparation of the genomic library by standard methods, DNA was digested with EcoRI and electrophoresed, and 4-9 kb fragments were excised from the gel and purified with GeneClean (Bio 101) (Sambrook et al., 1989). The fragments were ligated into similarly digested and dephosphorylated pBluescript II SK(-) (Stratagene). The ligation mixture was used to transform competent Escherichia coli XL1-Blue following the manufacturer's instructions (Stratagene).

DNA sequencing and sequence analysis. Both strands of the PCR product described above were sequenced using the fmol DNA Sequencing system (Promega). For the genomic clone, the insert was subcloned into pBluescript $\mathrm{SK}(+)$. Singlestranded DNA was obtained from both strands with M13 VCSM helper phage (Stratagene) and sequenced by the dideoxy chain-termination method using the Sequenase version 2 kit (USB) and custom-synthesized primers. The nucleotide and deduced amino acid sequence analyses were performed using the FASTA, GAP and MOTIFs programs of the Wisconsin Sequence Analysis Package version 8 (Genetics Computer Group, Madison, WI, USA). The protein homology search was performed using the BLAST network service of the National Center for Biotechnology Information.

Northern (RNA) blot analysis. Total RNA from C. albicans strain $3153 \mathrm{~A}$ grown under different conditions was extracted by the hot phenol method (Wise, 1991) and analysis was performed by standard procedures (Sambrook et al., 1989). Equal amounts of RNA as determined by $A_{260}$ measurements (Beckman DU-70 spectrophotometer) were electrophoresed and subsequently transferred to a nylon membrane (Nytran Plus; Schleicher \& Schuell) using the Turboblotter (Schleicher \& Schuell) following the manufacturer's instructions. The PCR product of the cDNA clone was obtained and ${ }^{32} \mathrm{P}$ labelled as described above and used for detection. Hybridization was performed using Rapid-hyb buffer (Amersham) following the manufacturer's instructions.

Preparation of affinity-purified antibody. The fusion protein specified by the cDNA clone was used to affinity-purify antibody as previously described (Alloush et al., 1996). The fusion protein was produced by the isolated $\lambda$ clone on solid medium and transferred to a nitrocellulose filter. The filter was incubated in the presence of the pooled polyclonal antisera for $3 \mathrm{~h}$. After the incubation period, the filter was exhaustively washed with buffer $(10 \mathrm{mM}$ Tris $/ \mathrm{HCl}, \mathrm{pH} 7 \cdot 4,0.9 \% \mathrm{NaCl}$ and $0.05 \%$ Tween 20). Bound antibody was eluted from the filter using $10 \mathrm{mM}$ glycine buffer ( $\mathrm{pH} 2 \cdot 3$ ) containing $0.9 \% \mathrm{NaCl}, 1 \%(\mathrm{w} / \mathrm{v}$ ) BSA and $0.05 \%$ Tween 20 (Casanova et al., 1991). The eluted antibody solution was neutralized with $2 \mathrm{M}$ Tris base.

Gel electrophoresis. SDS-PAGE using 5-15\% gradient acrylamide gels under denaturing conditions and Coomassie blue staining of the gel were performed as described previously by Casanova et al. (1989) and Laemmli (1970). Electrophoretic transfer to nitrocellulose paper (Schleicher \& Schuell) was 
performed basically as described by Burnette (1981), LópezRibot \& Chaffin (1994) and Towbin et al . (1979) using a semidry electroblotter (Hoeffer Scientific Instruments) at $0.8 \mathrm{~mA} \mathrm{~cm}^{-2}$ for $1 \mathrm{~h}$. In some experiments, samples were separated on $4-15 \%$ acrylamide gradient mini-gels (Bio-Rad).

Western blotting. Western blot analysis was performed as previously described (Alloush et al., 1996; Casanova et al., 1989), using undiluted affinity-purified antibody described above. A 1:2000 dilution of peroxidase-conjugated goat antirabbit IgG (Cappel; Organon Teknika) in Tris-buffered saline (TBS) $(10 \mathrm{mM}$ Tris/ $\mathrm{HCl}, \mathrm{pH} 7 \cdot 4 ; 0.9 \% \mathrm{NaCl})$ containing $0.05 \%$ Tween 20 and $1 \%(\mathrm{w} / \mathrm{v}$ ) BSA (TBSTB) was used as indicator antibody. Coloured reactive bands were developed with $\mathrm{H}_{2} \mathrm{O}_{2}$ and 4-chloro-1-naphthol (Hawkes, 1982).

Immunodot blotting. For an immunodot blot, different quantities $(5,2.5$ and $1.25 \mu \mathrm{g})$ of a commercially available purified Saccharomyces cerevisiae PGK (Sigma) diluted in TBS buffer were directly applied onto nitrocellulose paper (Schleicher \& Schuell) and allowed to dry. The immunublot procedure described above was then used with either the monovalent affinity-purified antibody to the fusion protein or the pooled polyclonal antisera against $C$. albicans cell wall extracts at a final concentration of $1: 1000$ in TBSTB.

Indirect immunofluorescence (IIF). IIF assays were performed on intact germinated yeast cells basically following the procedure described elsewhere (Alloush et al., 1996; Casanova et al., 1989). The affinity-purified antibody to the fusion protein and a fluorescein-conjugated goat anti-rabbit IgG (Boehringer Mannheim) secondary antibody were used sequentially. The affinity-purified antibody was concentrated fivefold using Centricon-10 tubes (Amicon) prior to use. Negative controls in which incubation with the first antibody was omitted showed no fluorescence. Cells were examined with a Nikon Labophot equipped for epifluorescence and pictures of the fluorescent samples were taken using a cooled $\left(-45^{\circ} \mathrm{C}\right)$ charge-couple device (CCD) camera (Star 1; Photometrics) as reported previously (López-Ribot \& Chaffin, 1994). The digital image was converted to a TIFF file and was processed for brightness and contrast and scaled (Imgworks; Silicon Graphics) and printed (Codonics printer).

Immunoelectron microscopy. C. albicans germ tubes were sprayed as a fine aerosol directly into a container placed in a $-196^{\circ} \mathrm{C}$ propane reservoir. Samples were then transferred to modules in substitution blocks containing dry acetone with $0.01 \% \mathrm{OsO}_{4}$ at $-85^{\circ} \mathrm{C}$ for $3-4 \mathrm{~d}$. Blocks were then brought gradually to $4{ }^{\circ} \mathrm{C}$ and washed several times in anhydrous acetone. Finally, Unicryl resin (Ted Pella) was infiltrated into the blocks, which were cured under UV light. Thin sections were obtained and placed on nickel grids, washed in PBS $\left(0.145 \mathrm{M} \mathrm{NaCl} ; 0.0081 \mathrm{M} \mathrm{Na}_{2} \mathrm{HPO}_{4} ; 0.0027 \mathrm{M} \mathrm{KCl} ; 0.0014 \mathrm{M}\right.$ $\mathrm{KH}_{2} \mathrm{PO}_{4}$ ) and blocked for $15 \mathrm{~min}$ with PBS containing $1 \%$ $(\mathrm{w} / \mathrm{v})$ BSA before being incubated for $3 \mathrm{~h}$ at room temperature in the presence of the monovalent affinity-purified antibody. After the incubation period, the sections were washed three times with PBS, and incubated for $1 \mathrm{~h}$ at room temperature in the presence of a 1:7 dilution of colloidal-gold-conjugated anti-rabbit antibody (EY Laboratories). After washing in PBS, sections were counter-stained with uranyl acetate and lead citrate. Samples were observed with a Hitachi H-600 microscope at $75 \mathrm{kV}$ and pictures were obtained. Control grids in which the first incubation step with the affinity-purified antibody was omitted were processed in parallel and showed no specific reactivity, with only some occasional gold particles observed.

PGK enzymic assays. PGK activity in the different preparations from C. albicans was assayed using the coupled system described by Scopes (1975). The assay mix comprised $30 \mathrm{mM}$ Tris $/ \mathrm{HCl}$ (pH 7.5), $10 \mathrm{mM}$ 3-phosphoglycerate (potassium salt), $50 \mathrm{mM} \mathrm{KCl}, 5 \mathrm{mM} \mathrm{MgSO}_{4}, 0.2 \mathrm{mM} \mathrm{Na}_{2} \mathrm{EDTA}$, $4 \mathrm{mM}$ ATP, approximately $0.1 \mathrm{mM} \mathrm{NADH}$ and $20-40 \mu \mathrm{g}$ glyceraldehyde-3-phosphate dehydrogenase $\mathrm{ml}^{-1}$ (specific activity $\left.50-100 \mathrm{IU} \mathrm{mg}^{-1}\right)$. Cells $\left(7-8 \times 10^{9}\right.$ from a $25 \mathrm{ml}$ yeast culture grown in YEPD at $25^{\circ} \mathrm{C}$ were collected by centrifugation and used in an assay. Culture supernatant $(25 \mathrm{ml})$ was dialysed and concentrated 400 -fold by lyophilization. Cytosol was prepared by breaking yeast cells in $10 \mathrm{mM}$ Tris/ $\mathrm{HCl}(\mathrm{pH} 7 \cdot 4)$ by vortexing with glass beads. The supernatant was removed from the settled glass beads, and debris and intact cells were removed by centrifugation. Aliquots containing 5 and $10 \mu \mathrm{g}$ protein as determined by $A_{280}$ measurements were assayed. Purified PGK from $S$. cerevisiae (Sigma) served as a positive control.

\section{RESULTS}

\section{Presence of a protein associated with CDNA clone $V$ in the cell wall and at the surface}

We have previously used cDNA clones and affinitypurified antibody to the fusion proteins specified by each clone as probes to study the expression of cell surface proteins (Alloush et al., 1996). The purpose of this study

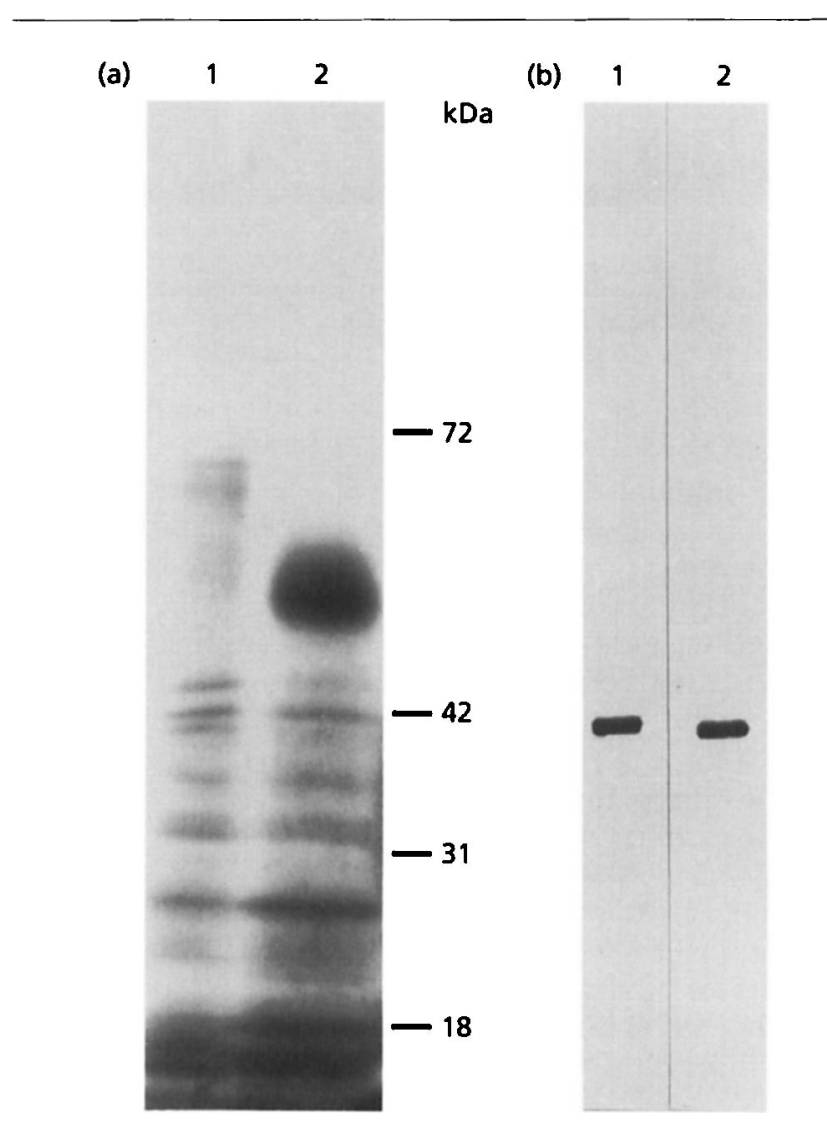

Fig. 1. Identification of cell wall proteins. $\beta$ ME cell wall extracts separated by SDS-PAGE were analysed by Coomassie blue staining (a) or by Western blotting using the affinity-purified antibody against the candidal PGK fusion protein (b). Extracts ( $300 \mu \mathrm{g}$ sugar per lane) were obtained from yeast cells (lanes 1 ) and germ tubes (lanes 2). Molecular masses of protein standards run in parallel are shown. 

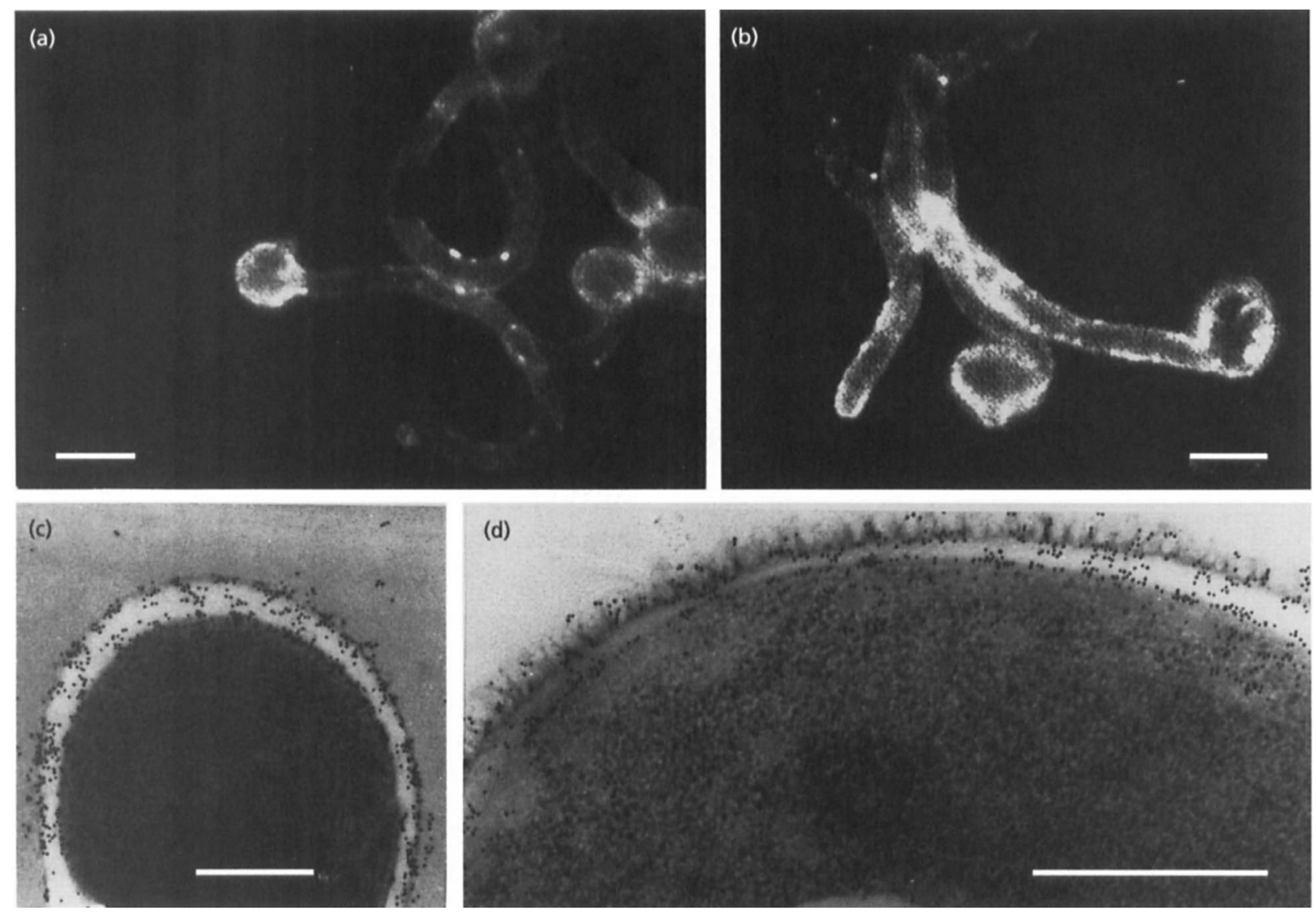

Fig. 2. Localization of protein using immunofluorescence and immunoelectron microscopy. The monovalent affinitypurified antibody against the fusion protein was used in an IIF assay ( $a, b$; bar $5 \mu \mathrm{m}$ ) and in immunoelectron microscopy (c, d; bar $0.5 \mu \mathrm{m}$ ) following procedures described in Methods.

was to examine the expression of one of these clones, originally designated clone $\mathrm{V}$, in greater detail. Among the numerous proteins which can be removed from the cell wall by alkaline extraction with $\beta \mathrm{ME}$, affinitypurified antibody to the fusion protein specified by clone $\mathrm{V}$ reacted with only a single protein band (Fig. 1). The $40 \mathrm{kDa}$ band was present in cell wall extracts from both yeast cells and germ tubes. Several affinity-purified antibody preparations had the same monovalent reactivity pattern, demonstrating the specificity of the affinity-purified antibody preparations for a single component. Affinity-purified antibody was used in an IIF assay to assess the expression of the protein on the cell surface of intact fungal cells (Fig. $2 a, b$ ). Both yeast cells and germ tubes were stained with the antibody preparation.

\section{Northern analysis}

Northern blot analysis with the clone V PCR product identified a $1.6 \mathrm{~kb}$ transcript (Fig. 3). The transcript was detected in RNA from cells growing in the yeast form in YEPD medium at 25 and $37^{\circ} \mathrm{C}$ and in Lee medium at $25^{\circ} \mathrm{C}$. It was also detected in RNA from cells obtained

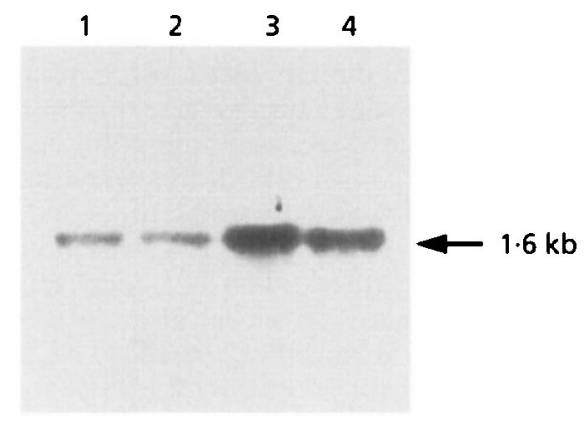

Fig. 3. Northern blot analysis of the candidal PGK1 transcript. RNA was obtained from $C$. albicans $3153 \mathrm{~A}$ growing as yeast cells in YEPD medium at 25 or $37^{\circ} \mathrm{C}$ (lanes 1 and 2 , respectively), as yeast cells in Lee medium at $25^{\circ} \mathrm{C}$ (lane 3 ) and $6 \mathrm{~h}$ after induction of germ tubes in Lee medium at $37^{\circ} \mathrm{C}$ (lane 4). Hybridization was performed as described in Methods. The size of the transcript was calculated by regression analysis of standards run in parallel.

$6 \mathrm{~h}$ following germ tube induction in Lee medium at $37^{\circ} \mathrm{C}$. Expression was also detected in RNA obtained from germ tubes 1 and $24 \mathrm{~h}$ after induction (data not 
1 MSLSKLTVK DLVVTCKRVP 50

K. lactis MSLSSKLTVK DLDVTGKRVR IRVDFNVPLD GKKITSNQRI VAALPTIQYV s. cerevisiae MSLSSKLSVQ DLDLKDKRVF IRVDFNVPLD GKKITSNQRI VAALPTIKYV C. maltosa MSLSNKLSVK DLNVTGKRVF IRVDFNVPLD GKTITNNQRI VAALPTIKYY C.albicans MSLSNKLSVK DLDVAGKRVF IRVDFNVPLD GKTITNNORI VAALPTIKYY Consensus MSLSNKLSVK DLDV-GKRVF IRVDFNVPLD GK-IT-NQRI VAALPTIKYV

K. Jactis LI 100 5. cerevisiae LEHHPRYVVL ASHLGRPNGE RNEKYSLAPV AKELOSLLGK DVTFLNDCVG c. mal tosa EEQKPKCIIL ASHLGRPNGE RNEKYSLAPV AAELEKLLGQ KVTFLDDCVG

C. albicans EEHKPKYIVL ASHLGRPNGE RNDKYSLAPV ATELEKLIGQ KVTFLNDCVG

Consengus -E-KPK-IVL ASHLGRPNGE RN-KYSLAPV A-EL--LLG- -VTFL-DCVG 101

150

K. lactis EEVTNAVNNA KDGEVFLLEN LRFHIGEEGS RK-VDGNKVK ADKAAVTKPRs. cerevisiae PEVEAAVKAS APGSVILLEN LRYHIEEEGS RK-VDGQKVK ASKEDVQKFR C. mal tosa PEVTKAVDSA TEGOIFLLEN LRFHIBEEGS AKDKDGKKTK ADPEAVKKFR c. maltosa PEVTKAVDSA TEGQIFLLEN LRFHIEEEGS AKDKDGKKTK ADPEAVKKFR albicans
Consensus
PEVT-AV--A --G--FLLEN LR-HIEEEGS -KD-DGKKVK AD-EAV-KFR 152

K. lactis

S. cerevisiae

c. maltosa

c. albicans

Consensus

200 MELSSLADVY INDAFGTAHR AHSSMVGFDL PORAAGFUT KET KYBGKAL EQLTSLADVY VNDAFGTAHR AHSSMVGIVV PEPAAGFLMS KELEYFAKAL

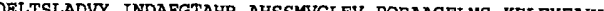
-ELTSLADVY INDAFGTAHR AHSSMVGLEV PQRAAGFLMS KELEYFAKAL 201

k. lactis ENPTRPFLAI LGGAKVADKI QLIDNLLDKV DSLIIGGGMA FTFKKVLENT s. cerevisiae ENPTRPFLAI LGGAKVADKI QLIDNLLDKV DSIIIGGGMA FTFKKVLENT

c. maltosa ENPQRPFLAI LGGAKVSDKI QLIDNLLDKV DMLIVGGGMA FTFKKVLNNM

c. albicans ENPERPFLAI LGGAKVSDKI QLIDNLLDKV DMLIVGGGMA FTFKXILNK

Consensus ENP-RPFLAI IGGAKV-DKI OLIDNLLDKV D-LI-GGGMA FTFKKVL-N-

251

K. Iactis EIGDSTYDAA GAELVPKLVE KAKKNNVKIV LPTDFVIGDK FSADAY 300

K. Jactio EIGDsIYDA GAELVPKLVE KAKRTMKIV LPTDFVIGDK gSADANTKV

c. maltosa PIGDSLFDEA GAKNVENLVA KAKKNNVELI LPVDFVTADK FDKDAEVSTA

c. albicans PIGDSLFDEA GAKNVEHLVE KAKKNNVELI LPVDFVTADK FDKDAKTSSA

Consensus -IGDS-FDEA GA--VE-LVE KAKKNNVE-- LPVDFV-ADK F--DA-T--.

301

K. lactis TDKEGIPSGW OGLDNGPESR KAFAATVAEA KTIVWNGPPG VFEFAPFAKG

. cereVisiae TDKEGIPAGW OGLDNGPESR KLFAATVAKA KTIVWNGPPG VEEFEKFAAG

c. maltosa DDVTGIPDKW MGLDCGPKSR KLFADAVAKA KTIVWNGPPG VFPFDKFAFG

C.

Consensus TD-EGIP--W -GLD-GP-SR KLFA--VAKA KTIVWNGPPG VFEF-KFA-G

cerevisia TMALDAVNA SSQAGNMVII GGGDTATVAK KYGVVDKISH VSTGGGASLE

CEYVIDL TKALIDEVVK SSAAGNTVII GGGDTATVAK KYGVTDKISH VSTGGGASLE

c. maItosa TKSLLDDAVK SAEVGNIVII GGGDTATVAK KYGVVDKLSH VSTGGGASL

c. albicans TKSLIDAAVK SAENGNIVII GGGDTATVAK KYGVVEKLSH VSTGGGASLE

Consensus TK-LID--VK SAE-GN-VII GGGDTATVAK KYGVDKLSH VSTGGGASLE

401 417

417

s. Cerevisiae LIEGKELPGV AFLSEKK

c. mal tosa LIEGKELPGV TALSNK

c. albicans LLEGKDLPGV VALSNKN

Consensus LLEGKELPGV --LSNK-

Fig. 4. Deduced amino acid sequence of the $C$ albicans $P G K 1$ product. The deduced sequence is shown with sequences of $K$. lactis, S. cerevisiae and C. maltosa. A consensus sequence (identity in three or four sequences) is shown below. A conserved amino acid sequence for PGK enzymes is underlined in the consensus sequence. Also identified was a consensus site for $\mathrm{N}$-glycosylation (349) in the $\mathrm{C}$. albicans sequence indicated with a double underline.

shown). The gene appeared to be expressed constitutively in both yeast cells and germ tubes.

\section{DNA sequence analysis}

The CDNA insert of clone $V$ was amplified and the PCR product was sequenced and used to isolate a clone from a genomic library in pBluescript II. A $2 \cdot 1 \mathrm{~kb}$ section of the genomic clone including the region corresponding to the cDNA clone was also sequenced. An open reading frame (ORF) for a 417 amino acid protein was found. The nucleotide sequence of the ORF was used for a database search. Extensive homology of the coding region was found with PGK genes. Homology of $88 \%$, $77 \%$ and $76 \%$ was observed over $1.2 \mathrm{~kb}$ with the genes from Candida maltosa (Masuda et al., 1994; accession nos D12474 and D01167), S. cerevisiae (Hitzeman et al., 1982; accession no. J01342) and Kluyveromyces lactis (Fournier et al., 1990; accession no. X17654), respectively. The deduced amino acid sequence (Fig. 4) contained the highly conserved signature motif for PGK (EC 2.7.2.3). Protein homology with other yeast sequences was noted for C. maltosa ( $89 \%$ identity, $95 \%$ similarity), S. cerevisiae ( $76 \%$ identity, $82 \%$ similarity) and $K$. lactis $(77 \%$ identity, $83 \%$ similarity). These observations strongly support the identification of the gene as $C$. albicans $P G K 1$. The sequence lacked a signal sequence generally associated with secreted proteins (von Heijne, 1986). An N-glycosylation site not present in $S$. cerevisiae was found at residue 349 . This site is very near the substrate-binding site. The $5^{\prime}$ non-proteincoding nucleotide region (Fig. 5) did not show similar homology to the $S$. cerevisiae sequence. Transcription of the $S$. cerevisiae $P G K 1$ gene is affected by a number of nuclear factors including RAP1 (Chambers et al., 1989), ABF1 (Chambers et al., 1990) and GCR1 (Henry et al., 1994). A heat-shock element is also found in the promoter region (Piper et al., 1988a). The $5^{\prime}$ region of PGK1 was examined for homology with the consensus sequences for these binding factors and for TATA sequences. Overlapping consensus TATA sequences were found at -150 and -152 (Fig. 5). Consensus sites for the other sequences were not found. Several possible TCAA transcription initiation sites (Hahn et al., 1985) were found between the TATA sequences and the putative translation start site. A 15 bp direct repeat was found before and after the TATA sequence at -102 and -186 , respectively.

\section{Reactivity of monovalent affinity-purified antibody with S. cerevisiae PGK protein}

To confirm the identification of the cloned sequence as the C. albicans PGK1 gene, we took advantage of the sequence conservation among species and the retention of common epitopes for antibody recognition. The reactivity of the monospecific affinity-purified antibody to the fusion protein produced by the cDNA clone was examined with a known PGK. An immunodot blot of purified PGK of $S$. cerevisiae showed reactivity with both the pooled polyclonal antiserum and the monovalent affinity-purified antibody (data not shown).

\section{Biotinylation of surface proteins}

Since PGK has not previously been described in the cell wall, we used two methods to demonstrate the moiety was a genuine cell wall component. In one approach, cell surface proteins external to the cell membrane were specifically labelled on intact cells with Sulfo-NHSbiotin, which does not permeate the cell membrane. The $\beta \mathrm{ME}$ extract was obtained and biotinylated proteins were purified by affinity chromatography on immobilized streptavidin. The purified proteins and unpurified 


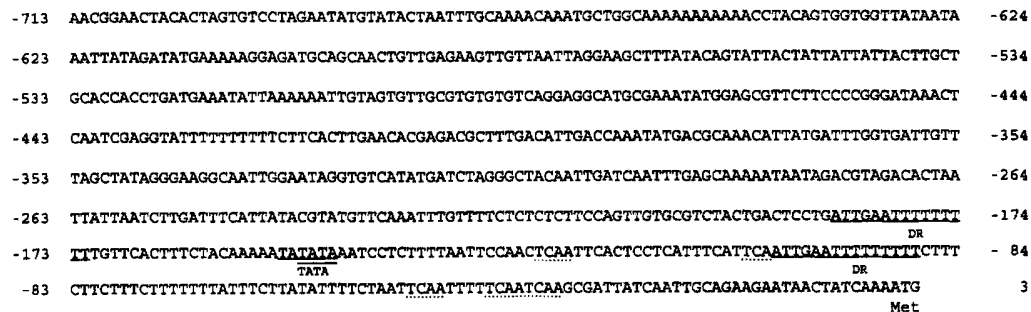

Fig. 5. Nucleotide sequence of the PGK1 promoter region. Two $15 \mathrm{bp}$ direct repeats (DR) and two overlapping TATA sequences are underlined in the nucleotide sequence. Possible TCAA transcription initiation sites are indicated by dots below the sequence.

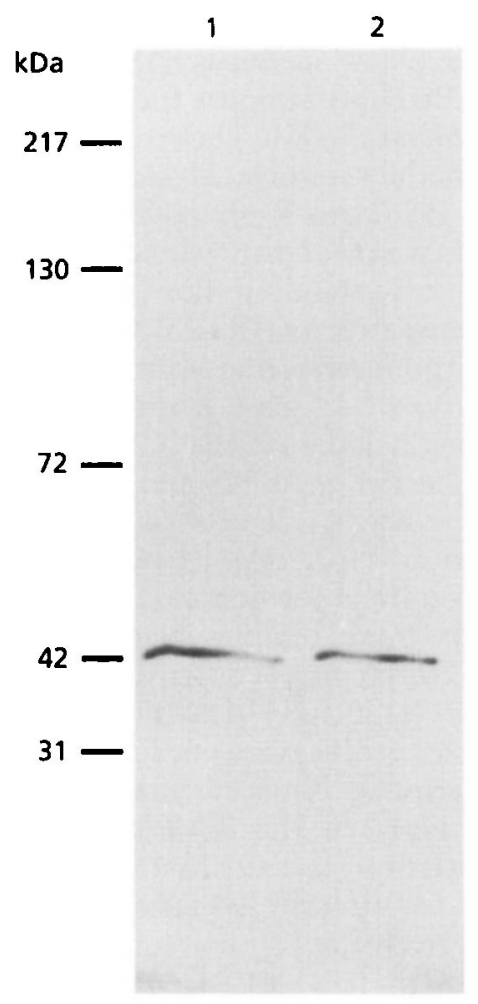

Fig. 6. Western blot analysis of biotinylated proteins. Unfractionated cell wall extract (lane 1) and biotinylated proteins purified from the extract by streptavidin affinity chromatography (lane 2) were separated by SDS-PAGE on a mini-gel and transferred to nitrocellulose. Monovalent affinitypurified antibody recognizing the cloned PGK fusion protein was used for the Western blot analysis. Electrophoretic mobility of protein standards run in parallel is indicated.

extract were analysed by Western blotting using the affinity-purified antibody (Fig. 6). The affinity-purified antibody reacted with a $40 \mathrm{kDa}$ protein in the total extract (lane 1) as well as in the purified biotinylated proteins (lane 2). Biotinylation of the cell wall component recognized by the antibody with Sulfo-NHSbiotin demonstrated that it was present outside of the cell plasma membrane prior to extraction and associated with the cell wall.

\section{Immunoelectron microscopy}

Additional evidence for the localization of PGK was obtained by immunoelectron microscopy. The monospecific affinity-purified antibody to the fusion protein containing the C. albicans PGK was used in indirect immunoelectron microscopy. As shown in Fig. 2(c, d), the moiety reacting with the monospecific affinitypurified antibody was present at the cell surface as well as the outer surface of the plasma membrane, and extended through the cell wall. Extensive reactivity was also detected in the cytoplasm as expected.

\section{Localization of enzyme activity}

To localize enzyme activity, the culture filtrate, intact cells and a cytosol fraction were examined for activity. No reactivity was observed in the concentrated culture filtrate while reactivity was just detectable with a suspension of whole cells. Essentially all of the detectable reactivity was in the cytosol fraction (data not shown).

\section{DISCUSSION}

Monovalent affinity-purified antibody to the fusion protein of one of the cDNA clones for cell wall antigens of C. albicans detected a $40 \mathrm{kDa}$ protein present in $\beta \mathrm{ME}$ extracts from yeast cells and germ tubes (Alloush et al., 1996; Fig. 1). The nucleotide sequence of the cDNA clone and a $2 \cdot 1 \mathrm{~kb}$ portion of a genomic clone encoding this antigen were highly homologous to genes for PGK. In particular, high homology was observed with the fungal $P G K$ genes from C. maltosa $(88 \%)$, S. cerevisiae $(77 \%)$ and $K$. lactis $(76 \%)$. PGK is found in all living organisms and contributes 1-5\% of mRNA and protein of S. cerevisiae (Holland \& Holland, 1978). Its sequence has been highly conserved (Watson \& Littlechild, 1990). The deduced amino acid sequence contained a highly conserved sequence found in the substrate-binding site (Fig. 4). At the protein sequence level, somewhat higher homology than at the nucleotide level was observed. There was $95 \%, 83 \%$ and $82 \%$ similarity with sequences from C. maltosa, K. lactis and S. cerevisiae, respectively. The observation that both the affinitypurified monovalent antibody against the fusion protein and a pooled polyclonal antiserum preparation against C. albicans cell wall extracts showed cross-reactivity against the purified PGK enzyme from $S$. cerevisiae confirmed that we had cloned the C. albicans PGK1 gene. Using the $S$. cerevisiae gene as a heterologous probe under conditions of high stringency, Manavathu (1993) reported that $P G K 1$ is a single copy gene present on the large chromosome (presumably R) of C. albicans.

Two overlapping TATA consensus sequences were present in the $5^{\prime}$ region of the gene (Fig. 5). Also present 
downstream of the TATA sequences were several TCAA sequences that are used in some $S$. cerevisiae genes as transcription initiation sites (Hahn et al., 1985). The transcription of PGK1 in S. cerevisiae is not dependent on the TATA sequence and is affected by a number of other transcriptional regulators (Ogden et al., 1986). These include RAP1 (Chambers et al., 1989), ABF1 (Chambers et al., 1990) and GCR1 (Henry et al., 1994) and the GAL11 co-activator (Stanway et al., 1994) proteins. A heat-shock element is also found in the promoter region (Piper et al., 1988a) and several enzymes of the glycolytic pathway, including PGK, are induced after heat shock (Piper et al., 1988b; Mager \& MoradasFerreira, 1993). A consensus match for the RAP1, ABF1, GCR1 and heat-shock element sequences was not observed. These regulatory elements found in S. cerevisiae either are missing or deviate from the consensus sequence in the C. albicans PGK1 (Fig. 5). The nonprotein-coding regions of the pyruvate kinase genes (PYK1) of C. albicans and S. cerevisiae have less homology than the coding region (Swoboda et al., 1993). Thus the regulation of glycolytic gene expression may vary from that observed in $S$. cerevisiae, even though the structural genes have a high degree of homology.

Northern blot analysis revealed that PGK1 was constitutively expressed, a not unexpected finding after the identification of the gene and growth in glucosecontaining medium (Fig. 3). PGK1 was expressed in cells growing in different media, at different temperatures and with different morphologies. The expression of four glycolytic genes, PYK1, alcohol dehydrogenase (ADH1), phosphoglycerate mutase (GPM1) and PGK1, has been examined in C. albicans (Swoboda et al., 1994). In general, the mRNA levels decreased upon inoculation of cells into fresh medium and recovered more rapidly at $37^{\circ} \mathrm{C}$ than at $25^{\circ} \mathrm{C}$. No evidence was found for a heatshock response. Alterations appeared to be associated with changes in cellular physiology rather than in temperature or morphology. The observations in this study are in general agreement as the PGK1 transcript was measured in yeast cells that had been in exponential growth for several hours, and the first measurement on a germ tube culture was $1 \mathrm{~h}$ after induction. These conditions are sufficient to permit the restoration of mRNA following the transient decrease observed by Swoboda et al. (1994).

Several lines of indirect evidence supported the conclusion that PGK was a cell wall protein. (1) The presence of a component at the cell surface or in cell wall extracts has been a criterion for defining a cell wall protein and used as a classification scheme (see reviews and references in Calderone, 1993; Calderone \& Braun, 1991; Hostetter, 1994; Pontón et al., 1993). (2) The method of preparation of cell wall extracts has been shown to include genuine cell wall components and exclude cytosolic contaminants including a glycolytic enzyme (Casanova et al., 1992; Chaffin \& Stocco, 1983). Such extracts were used in the preparation of antiserum and in the identification of the protein specified by the cDNA clone (Fig. 1). (3) The absence of the enzyme in the culture filtrate did not support a hypothesis of nonspecific coating of the surface, following lysis of a few cells. Enolase, but not glyceraldehyde-3-phosphate dehydrogenase activity, is found in the culture filtrate but enolase does not coat the surface of cells in the culture (Sundstrom \& Aliaga, 1992, 1994; Angiolella et al., 1996). However, the identification of a protein in the cell wall as a glycolytic enzyme prompted us to use additional means to demonstrate the validity of this finding. First, biotinylation of intact cells with SulfoNHS-biotin demonstrated that PGK was present outside the cell membrane and associated with the cell wall (Fig. 6). Candidal PGK was localized using immunoelectron microscopy (Fig. 2). Using the monovalent affinitypurified antibody against the fusion protein, reactivity was detected at the cell surface as well as the outer surface of the plasma membrane, and extended through the cell wall. Reactivity was also detected throughout the cytoplasm as expected. These results confirmed that PGK is also a genuine component in the cell wall of $C$. albicans.

The presence of glycolytic enzymes on microbial surfaces is not unprecedented. Recently, Angiolella et al. (1996) demonstrated that enolase is present in the cell wall but not present on the cell surface of C. albicans. We have confirmed that enolase is present in the cell wall extracts but do not detect reactivity at the cell surface by IIF (data not shown). Glyceraldehyde-3-phosphate dehydrogenase has been reported as a major surface protein on group A streptococci (Streptococcus pyogenes), where it not only is enzymically active but serves as a binding protein for fibronectin, lysozyme, myosin and actin (Pancholi \& Fischetti, 1992). In Kluyveromyces marxianus, the same enzyme protein has been identified as a constitutive protein of the cell wall that increases substantially upon induction of flocculation (Fernandes et al., 1992). Alcohol dehydrogenase is also a surface protein of Entamoeba histolytica, where it has been reported to display receptor activities for a number of extracellular matrix components (Yang et al., 1994). This protein has also been suggested to be present on the surface of $C$. albicans, perhaps as a fibronectin or vitronectin receptor (Pendrak \& Klotz, 1995). Recently, PGK has been found on the outer covering (tegument) of the parasite Schistosoma mansoni (Lee et al., 1995).

We have recently demonstrated that a member of the hsp70 family of proteins is present in the cell wall of $C$. albicans (López-Ribot $e t$ al., 1996). We have also shown that the products of SSA1 and SSA2, two members of the HSP70 gene family in S. cerevisiae, are present in the cell wall of that organism. Mutants lacking both of these genes have no detectable hsp70 in cell wall extracts while other members of the hsp70 family are detectable in the cytoplasm of the mutant (López-Ribot \& Chaffin, 1996). These observations further confirm that the presence of such proteins in cell wall extracts is not attributable to contamination.

The presence of PGK in the cell wall has at least two implications for secretion or cellular targeting. First, it requires a mechanism that apportions PGK between the 
cytoplasm and the cell wall. Secondly, the absence of a conventional N-terminal signal sequence (von Heijne, 1986) found on most secretory proteins, including those of C. albicans (Livi et al., 1991), suggests an alternative mechanism of secretion to the classical endoplasmic reticulum/golgi secretory pathway. A $47 \mathrm{kDa}$ immunodominant antigen found in the cell wall by immunoelectron microscopy is a peptide fragment of an hsp90 (Matthews \& Burnie, 1989; Matthews et al., 1988) and also would appear to require an alternative mechanism to reach the cell wall. The hsp70 proteins do not have a conventional signal sequence and in $S$. cerevisiae, a mutant lacking hsp70 in the cell wall is also altered in the profile of proteins present in the wall (López-Ribot \& Chaffin, 1996). As a molecular chaperone implicated in transport of proteins across membranes (Craig et al., 1994), one possibility is that hsp70 may be involved in the secretion of proteins lacking a signal sequence. A number of prokaryotic, fungal and higher eukaryotic proteins appear to utilize a non-classical pathway and some of these pathways have been described by Kuchler (1993).

There have been a number of recent reports indicating that several candidal glycolytic enzymes elicit an immune response. Enolase is known to be an abundant immunodominant antigen in C. albicans, and it has been found to be secreted to the liquid medium (Sundstrom \& Aliaga, 1992, 1994; Walsh et al., 1991) and present in the cell wall (Angiolella et al., 1996). Antibodies to candidal pyruvate kinase and alcohol dehydrogenase in the sera from patients suffering from superficial candidiasis have also been reported (Swoboda et al., 1993). Candidal glycolytic enzymes, including PGK, are also reactive with immunoglobulin $E$ antibody present in the sera from allergic patients (Ishiguro et al., 1992; Shen et al., 1991). We are presently examining the presence of antibodies against PGK in serum from individuals with candidiasis.

In summary, we have shown that PGK is a bona fide cell wall protein of C. albicans. The function of this protein - enzymic, receptor, or some other function - in the cell wall is yet to be determined. However, the presence in the cell wall of such proteins having enzymic functions in the cytosol raises provocative questions about multiple functions of proteins and cellular partitioning.

\section{ACKNOWLEDGEMENTS}

This work was supported by Public Health Service Grant AI 23416 from the National Institutes of Health to W.L.C. J.L.L.R. acknowledges the receipt of an OTAN-MEC postdoctoral fellowship (Ministerio de Educación y Ciencia, Spain). We thank Mark Grimson, Charles Butterick and the staff of the Electron Microscopy Center for assistance with electron microscopy.

\section{REFERENCES}

Alloush, H. M., López-Ribot, J. L. \& Chaffin, W. L. (1996). Dynamic expression of cell wall proteins of Candida albicans revealed by probes from cDNA clones. J Med Vet Mycol 34, 91-97.

Angiolella, L., Facchin, M., Stringaro, A., Maras, B., Simonetti, N.
\& Cassone, A. (1996). Identification of a glucan-associated enolase as a main cell wall protein of Candida albicans and an indirect target of lipopeptide antimycotics. J Infect Dis 173, 684-690.

Ausubel, F., Brent, R., Kingson, R., Moor, D., Seidman, J., Smith, J. \& Struhle, K. (1988). Current Protocols in Molecular Biology. New York: Wiley Intersciences.

Burnette, W. N. (1981). "Western blotting": electrophoretic transfer of proteins from sodium dodecyl sulfate-polyacrylamide gels to unmodified nitrocellulose and radiographic detection with antibody and radioiodinated protein A. Anal Biochem 112, 195-203.

Calderone, R. A. (1993). Recognition between Candida albicans and host cells. Trends Microbiol 1, 55-58.

Calderone, R. A. \& Braun, P. C. (1991). Adherence and receptor relationships in Candida albicans. Microbiol Rev 55, 1-20.

Casanova, M. \& Chaffin, W. L. (1991). Cell wall glycoproteins of Candida albicans as released by different methods. J Gen Microbiol 137, 1045-1051.

Casanova, M., Gil, M. L., Cardeñoso, L., Martínez, J. P. \& Sentandreu, R. (1989). Identification of wall specific antigens synthesized during germ tube formation by Candida albicans. Infect Immun 57, 262-271.

Casanova, M., Martínez, J. P. \& Chaffin, W. L. (1990). Fab fragments from a monoclonal antibody against a germ tube specific mannoprotein block yeast-to-mycelium transition in Candida albicans. Infect Immun 58, 3810-3812.

Casanova, M., Martínez, J. P. \& Chaffin, W. L. (1991). Identification of germ tube cell wall antigens of Candida albicans. $J$ Med Vet Mycol 29, 269-272.

Casanova, M., López-Ribot, J. L., Martínez, J. P. \& Sentandreu, R. (1992). Characterization of cell wall proteins from yeast and mycelial cells of Candida albicans by labelling with biotin: comparison with other techniques. Infect Immun 60, 4898-4906.

Cassone, A. (1989). Cell wall of Candida albicans: its functions and its impact on the host. Curr Top Med Mycol 3, 53-70.

Chaffin, W. L. \& Stocco, D. M. (1983). Cell wall proteins of Candida albicans. Can J Microbiol 29, 1438-1444.

Chambers, A., Tsang, J. S. H., Stanway, C., Kingsman, A. J. \& Kingsman, S. M. (1989). Transcriptional control of the Saccharomyces cerevisiae PGK gene by RAP1. Mol Cell Biol 9, 5516-5524.

Chambers, A., Stanway, A., Tsang, J. S. H., Henry, Y., Kingsman, A. J. \& Kingsman, S. M. (1990). ARS binding factor 1 binds adjacent to RAP1 and the UASs of the yeast glycolytic genes PGK and PYK1. Nucleic Acids Res 18, 5393-5399.

Cole, S. R., Ashman, L. K. \& Ev, P. L. (1987). Biotinylation: an alternative to radioiodination for the identification of cell surface antigens in immunoprecipitates. Mol Immunol 24, 699-705.

Craig, E. A., Baxter, B. K., Becker, J., Halladay, J. \& Ziegelhoffer, T. (1994). Cytosolic hsp70s of Saccharomyces cerevisiae: roles in protein synthesis, protein translocation, proteolysis, and regulation. In The Biology of Heat Shock Protein and Molecular Chaperones, pp. 31-52. Edited by R. I. Morimoto, A. Tissieres \& C. Georgopoulous. Cold Spring Harbor, NY: Cold Spring Harbor Laboratory.

Cutler, J. E. (1991). Putative virulence factors for Candida albicans. Annu Rev Microbiol 45, 187-218.

Dubois, M., Gilles, K. A., Hamilton, J. K., Rebers, P. A. \& Smith, F. (1956). Colorimetric method for determination of sugars and related substances. Anal Chem 28, 350-356.

Fernandes, P. A., Keen, J. N., Findlay, J. B. C. \& Moradas-Ferreira, P. (1992). A protein homologous to glyceraldehyde-3-phosphate 
dehydrogenase is induced in the cell wall of a flocculent Kluyveromyces marxianus. Biochim Biophys Acta 1159, 67-73.

Fournier, A., Fleer, R., Yeh, P. \& Mayaux, J. (1990). The primary structure of the 3-phosphoglycerate kinase (PGK) gene from Kluyveromyces lactis. Nucleic Acids Res 18, 365.

Hahn, S., Hoar, E. T. \& Guarente, L. (1985). Each of three 'TATA elements' specifies a subset of the transcription initiation sites at the CYC-1 promoter of Saccharomyces cerevisiae. Proc Natl Acad Sci USA 82, 8562-8566.

Hawkes, R. (1982). Identification of concanavalin A-binding proteins after sodium dodecyl sulfate-gel electrophoresis and protein blotting. Anal Biochem 123, 143-146.

von Heijne, G. (1986). A new method for predicting signal sequence cleavage sites. Nucleic Acids Res 14, 4683-4690.

Henry, Y. A. L., López, M. C., Gibbs, J. M., Chambers, A., Kingsman, S. M., Baker, H. V. \& Stanway, C. A. (1994). The yeast protein Gcr1p binds to the PGK UAS and contributes to the activation of transcription of the PGK gene. Mol Gen Genet 245, 506-511.

Hitzeman, R. A., Hagie, F. E., Hayflick, J. S., Chen, C. Y., Seeburg, P. H. \& Derynck, R. (1982). The primary structure of the Saccharomyces cerevisiae gene for 3-phosphoglycerate kinase. Nucleic Acids Res 10, 7791-7808.

Holland, M. J. \& Holland, J. P. (1978). Isolation and identification of yeast messenger ribonucleic acids coding for enolase, glyceraldehyde-3-phosphate dehydrogenase, and phosphoglycerate kinase. Biochemistry 17, 4900-4907.

Hostetter, M. K. (1994). Adhesins and ligands involved in the interaction of Candida spp. with epithelial and endothelial surfaces. Clin Microbiol Rev 7, 29-42.

Ishiguro, A., Homma, M., Torii, S. \& Tanaka, K. (1992). Identification of Candida albicans antigens reactive with immunoglobulin $\mathrm{E}$ antibody of human sera. Infect Immun 60, 1550-1557.

Kuchler, K. (1993). Unusual routes of protein secretion: the easy way out. Trends Cell Biol 3, 421-426.

Laemmli, U. K. (1970). Cleavage of structural proteins during the assembly of the head of bacteriophage T4. Nature 227, 680-685.

Lee, K. L., Buckley, M. R. \& Campbell, C. (1975). An amino acid liquid synthetic medium for development of mycelial and yeast forms of Candida albicans. Sabouraudia 13, 148-153.

Lee, K. W., Shalaby, K. A., Thakur, A., Medhat, A. M., Karim, A. M. \& LoVerde, P. T. (1995). Cloning of the gene for phosphoglycerate kinase from Schistosoma mansoni and characterization of its gene product. Mol Biochem Parasitol 71, 221-231.

Livi, G. P., Lillquist, J. S., Miles, L. M., Ferrara, A., Sather, G. M., Simon, P. L., Meyers, C. A., Gorman, J. A. \& Young, P. R. (1991). Secretion of $N$-glycosylated interleukin- $1 \beta$ in Saccharomyces cerevisiae using a leader peptide from Candida albicans. J Biol Chem 266, 15348-15355.

López-Ribot, J. L. \& Chaffin, W. L. (1994). Binding of the extracellular matrix component entactin to Candida albicans. Infect Immun 62, 4564-4571.

López-Ribot, J. L. \& Chaffin, W. L. (1996). Members of the hsp70 family of proteins in the cell wall of Saccharomyces cerevisiae. $J$ Bacteriol 178, 4724-4726.

López-Ribot, J. L., Alloush, H. M., Masten, B. J. \& Chaffin, W. L. (1996). Evidence for presence in the cell wall of Candida albicans of a protein related to the hsp70 family. Infect Immun 64, 3333-3340.

Mager, W. H. \& Moradas-Ferreira, P. (1993). Stress response of yeast. Biochem J 290, 1-13.
Manavathu, E. K. (1993). Chromosomal localization of phosphoglycerate kinase (PGK) gene in Candida albicans using a heterologous probe. Indian J Exp Biol 31, 206-209.

Martínez, J. P., López-Ribot, J. L., Gil, M. L., Sentandreu, R. \& Ruiz-Herrera, J. (1990). Inhibition of the dimorphic transition of Candida albicans by the ornithine decarboxylase inhibitor 1,4diaminobutanone: alterations in the glycoprotein composition of the cell wall. J Gen Microbiol 136, 1937-1943.

Masuda, Y., Park, S. M., Ohkuma, M., Ohta, A. \& Takagi, M. (1994). Expression of an endogenous and a heterologous gene in Candida maltosa by using a promoter of a newly-isolated phosphoglycerate kinase (PGK) gene. Curr Genet 25, 412-417.

Matthews, R. \& Burnie, J. (1989). Cloning of a DNA sequence encoding a major fragment of the 47 kilodalton stress protein homologue of Candida albicans. FEMS Microbiol Lett 60, 25-30.

Matthews, R., Wells, C. \& Burnie, J. (1988). Characterization and cellular localization of the immunodominant $47 \mathrm{kDa}$ antigen of Candida albicans. J Med Microbiol 27, 227-232.

Ogden, J. E., Stanway, C., Kim, S., Mellor, J., Kingsman, A. J. \& Kingsman, S. M. (1986). Efficient expression of the Saccharomyces cerevisiae $P G K$ gene depends on an upstream activation sequence but does not require TATA sequences. Mol Cell Biol 6, 4335-4343.

Pancholi, V. \& Fischetti, V. A. (1992). A major surface protein on group A streptococci is a glyceraldehyde-3-phosphate dehydrogenase with multiple binding activity. J Exp Med 176, 415-426.

Pendrak, M. L. \& Klotz, S.A. (1995). Adherence of Candida albicans to host cells. FEMS Microbiol Lett 129, 103-114.

Piper, P. W., Curran, B., Davies, M. W., Hirst, K., Lockheart, A., Ogden, J. E., Stanway, C. A., Kingsman, A. J. \& Kingsman, S. M. (1988a). A heat shock element in the phosphoglycerate kinase gene promoter of yeast. Nucleic Acids Res 16, 1333-1348.

Piper, P. W., Curran, B., Davies, M. W., Hirst, K., Lockheart, A. \& Seward, K. (1988b). Catabolite control of the elevation of PGK mRNA levels by heat shock in Saccharomyces cerevisiae. Mol Microbiol 2, 353-361.

Pontón, J., Marot-Lebond, A., Exkurra, P., Barturen, B., Robert, R. \& Senet, J. M. (1993). Characterization of Candida albicans cell wall antigens with monoclonal antibodies. Infect Immun 61, 4842-4847.

Sambrook, J. F., Fritsch, E. F. \& Maniatis, T. (1989). Molecular Cloning: a Laboratory Manual, 2nd edn. Cold Spring Harbor, NY: Cold Spring Harbor Laboratory.

Scopes, R. K. (1975). 3-Phosphoglycerate kinase of skeletal muscle. Methods Enzymol 42, 127-138.

Shen, H. D., Choo, K. B., Lee, H. H., Hsieh, J. C., Lin, W. L., Lee, W. R. \& Han, S. H. (1991). The 40-kilodalton allergen of Candida albicans is an alcohol dehydrogenase: molecular cloning and immunological analysis using monoclonal antibodies. Clin Exp Allergy 21, 675-681.

Stanway, C. A., Gibbs, J. M., Kearsey, S. E., López, M. C. \& Baker, H. V. (1994). The yeast co-activator GAL11 positively influences transcription of the phosphoglycerate kinase gene, but only when RAP1 is bound to its upstream activation sequence. Mol Gen Genet 243, 207-214.

Sundstrom, P. M. \& Aliaga, G. R. (1992). Molecular cloning of cDNA and analysis of protein secondary structure of Candida albicans enolase, an abundant, immunodominant glycolytic enzyme. J Bacteriol 174, 6789-6799.

Sundstrom, P. M. \& Aliaga, G. R. (1994). A subset of proteins found in culture supernatants of Candida albicans includes the 
abundant, immunodominant, glycolytic enzyme enolase. $J$ Infect Dis 169, 452-456.

Swoboda, R. K., Bertram, G., Hollander, H., Greenspan, D., Greenspan, J. S., Gow, N. A. R., Gooday, G. W. \& Brown, A. J. P. (1993). Glycolytic enzymes of Candida albicans are nonubiquitous immunogens during candidiasis. Infect Immun 61, $4263-4271$.

Swoboda, R. K., Bertram, G., Delbruck, J. F., Gow, N. A. R., Gooday, G. W. \& Brown, A. J. P. (1994). Fluctuations in glycolytic mRNA levels during morphogenesis in Candida albicans reflect underlying changes in growth and are not a response to cellular dimorphism. Mol Microbiol 13, 663-672.

Towbin, H., Staehelin, T. \& Gordon, J. (1979). Electrophoretic transfer of proteins from polyacrylamide gels to nitrocellulose sheets : procedure and some applications. Proc Natl Acad Sci USA 76, 4350-4354.

Walsh, T. J., Hathorn, J. W., Sobel, J. D., Merz, W. G., Sanchez, V.,
Maret, S. M., Buckley, H. R., Pfaller, M. A., Schaufele, R., Sliva, C., Navarro, E., Lecciones, J., Chandraseka, P., Lee, J. \& Pizzo, P. A. (1991). Detection of circulating Candida enolase by immunoassay in patients with cancer and invasive candidiasis. $N$ Engl J Med 324, 1026-1031.

Watson, H. C., \& Littlechild, J. A. (1990). Isoenzymes of phosphoglycerate kinase: evolutionary conservation of the structure of this glycolytic enzyme. Biochem Soc Trans 18, 187-190.

Wise, J. A. (1991). Preparation and analysis of low molecular weight RNAs and small ribonucleoproteins. Methods Enzymol 194, 405-415.

Yang, W., Li, E., Kairong, T. \& Stanley, S. L., Jr (1994). Entamoeba bistolytica has an alcohol dehydrogenase homologous to the multifunctional adhE gene product of Escherichia coli. Mol Biochem Parasitol 64, 253-260.

Received 17 June 1996; revised 31 July 1996; accepted 21 August 1996. 